OPEN ACCESS

Edited by:

Nienke Biermasz,

Leiden University, Netherlands

Reviewed by:

Jacqueline Trouillas,

Claude Bernard University Lyon 1,

France

Leila Warszawski,

Instituto Estadual de Diabetes e

Endocrinologia Luiz Capriglione, Brazil

*Correspondence:

Odelia Cooper

odelia.cooper@cshs.org

Specialty section:

This article was submitted to

Pituitary Endocrinology,

a section of the journal

Frontiers in Endocrinology

Received: 08 March 2018

Accepted: 30 July 2018

Published: 21 August 2018

Citation:

Cooper O and Greenman Y (2018)

Dopamine Agonists for Pituitary

Adenomas. Front. Endocrinol. 9:469.

doi: 10.3389/fendo.2018.00469

\section{Dopamine Agonists for Pituitary Adenomas}

\author{
Odelia Cooper $^{1 *}$ and Yona Greenman ${ }^{2}$ \\ ${ }^{1}$ Pituitary Center, Cedars-Sinai Medical Center, Los Angeles, CA, United States, ${ }^{2}$ Institute of Endocrinology, Metabolism and \\ Hypertension, Tel Aviv-Sourasky Medical Center, Sackler Faculty of Medicine, Tel Aviv University, Tel Aviv, Israel
}

Dopamine agonists (DA) are well established as first-line therapy for prolactinomas. These tumors express high levels of dopamine 2 receptors (D2R), leading to the strong efficacy of DA in reducing tumor size and hormonal secretion. Other pituitary tumor subtypes express D2R to varying degrees, leading to an extensive body of research into potential off-label use of DA in non-prolactinoma pituitary tumors. Preclinical models of Cushing's disease, acromegaly, and nonfunctioning pituitary tumors (NFPT) demonstrate D2R expression in cell lines and cultured tumors as well as effectiveness of DA in reducing hormonal secretion in functioning tumors and arresting tumor proliferation. Clinical studies have shown some efficacy of DA in treatment of these tumors. In Cushing's disease, DA therapy results in normalization of urinary cortisol levels in approximately $25 \%$ of patients, but reported rates of tumor shrinkage are very low; in acromegaly, DA therapy leads to normalization of insulin-like growth factor I and tumor shrinkage in approximately one-third of patients, and improved responses when used in combination with somatostatin receptor ligands. Among patients with NFPT, pooled results show $30 \%$ experience reduction of tumor size and $58 \%$ show stabilization of disease. DA therapy appears to have some clinical benefit in patients with non-prolactinoma pituitary tumors, and may be an option for medical therapy in some clinical scenarios.

Keywords: dopamine agonist, pituitary adenoma, nonfunctioning pituitary tumor, Cushing's disease, acromegaly

\section{INTRODUCTION}

Dopamine modulates pituitary hormone secretion through the dopamine subtype 2 receptor (D2R). Dopamine binding to D2R in pituitary cells activates signaling cascades, leading to adenylyl cyclase and phosphatidylinositol metabolism inhibition, potassium channel activation, and reduced L-type and T-type calcium currents (1). Dopamine agonists (DA) targeting D2R yield excellent therapeutic response in prolactinomas and are the established first-line treatment (2).

$\mathrm{D} 2 \mathrm{R}$ is mainly expressed in lactotrophs, but has been localized to all anterior pituitary cell types (3), leading to off-label evaluation of cabergoline, bromocriptine, and quinagolide as DA treatment in other pituitary tumors. This review focuses on the use of DA in Cushing's disease (CD), acromegaly, and nonfunctioning pituitary tumors (NFPT). Although many studies explored measurements of D2R expression as a predictor of response to DA therapy, this remains primarily a research tool. In current clinical practice, D2R expression is likely limited as a predictor of response to DA therapy. 


\section{CUSHING'S DISEASE}

\section{Preclinical Studies}

Murine and cell-line studies indicate D2R is a potential target in $\mathrm{CD}$. The intermediate lobe of the pituitary in rodents is under tonic inhibition by hypothalamic dopaminergic neurons acting through D2R (4), and is hypertrophied in D2R-deficient mice, exhibiting increased expression of adrenocorticotropic hormone $(\mathrm{ACTH})$ and its precursor proopiomelanocortin (POMC). Bromocriptine inhibited proliferation and induced apoptosis of mouse pituitary corticotroph ACTH-secreting AtT20 cells $(5,6)$. Similarly, cabergoline treatment of cultured tumors in canine CD moderately expressing D2R mRNA attenuated ACTH secretion (7).

Up to $75 \%$ of human corticotroph adenomas express D2R (8, 9). In 15 of $20 \mathrm{ACTH}$-secreting adenomas, D2R immunostaining was moderate or strong, and D2R mRNA was detected in 10 of 12 cases. DR2-expressing primary tumor cell cultures showed dose-dependent ACTH inhibition with bromocriptine and cabergoline, whereas tumors not expressing D2R did not respond (8).

It is unclear whether corticotroph tumor features affect D2R expression. D2R mRNA was detected in 5 of 8 ACTHsecreting tumors and in 6 of 8 silent corticotroph adenomas (10), suggesting D2R expression may be seen across all corticotroph subtypes. However, correlation between D2R mRNA and protein expression in this study was poor. Others found lower D2R mRNA expression levels in overt or subclinical CD adenomas vs. silent ACTH-producing tumors (11), as well as higher expression levels in noninvasive microadenomas vs. higher-grade adenomas (12). Although data are limited, it is possible that such tumor features influence D2R expression levels, potentially affecting DA effectiveness.

\section{Clinical Efficacy}

Cabergoline has been studied as primary therapy for CD and in patients with relapsed or recurrent disease. In a review of 5 studies including 88 patients followed for 3-60 months, 25-40\% of cases saw remission, with a subsequent escape rate of $16 \%$ (13). Pooled results of published series show that $25 \%$ of patients respond with normalization of 24-h urinary free cortisol (UFC) secretion (Table 1).

Patients who respond to DA therapy may achieve complete (defined as normalized UFC) or partial response (variably defined as $25 \%$ or $50 \%$ decrease in UFC from baseline, or $<125 \%$ ULN) by 3-6 months after treatment initiation $(8,14,15,19,27)$. Dose escalation may enhance efficacy in patients who initially achieved partial response, but escape may occur within $<2$ years $(14,15,17)$.

Pivonello et al. treated $10 \mathrm{CD}$ patients for 3 months with escalating doses of cabergoline starting at $1 \mathrm{mg} /$ week and increasing $1 \mathrm{mg} /$ week until UFC normalization was achieved; 4 had a complete response and 2 had a partial response (8). Extending treatment in an additional 10 patients yielded response in 15 of 20 subjects by month 3, with 6 of 8 partial responders achieving UFC normalization after 6-12 months. Of note, 2 complete responders and 3 partial responders escaped treatment after 12-18 months. At 12 months, 10 subjects were controlled on a median cabergoline dose of $6 \mathrm{mg} /$ week; at 24 months, only 8 were still controlled and overall efficacy was calculated at $40 \%$ (14).

In a larger study of 30 patients with CD, 27 of whom had relapsed/recurrent disease, Godbout et al. reported 11 complete responders and 4 partial responders with a mean cabergoline dose of $1.5 \mathrm{mg} /$ week and an average time to normalization of 4.2 months. Nine of 11 complete responders maintained eucortisolemia while on treatment for a mean of 37 months, for an overall response rate of 30\%; partial responders saw UFC increase after 6 months (15).

Finally, Ferriere et al. reported on a multicenter retrospective study of $53 \mathrm{CD}$ patients, 44 of whom had relapsed/recurrent disease, who were treated with a mean cabergoline dose of $2.5 \mathrm{mg} /$ week for a median of 7 months. In the first year, 21 patients (40\%) achieved complete response and 4 achieved partial response; mean cabergoline dose in responders was $1.5 \mathrm{mg} /$ week (range, $0.5-4.0 \mathrm{mg} /$ week). After more than 1 year, 7 of 18 relapsed and required increased treatment doses; 3 achieved secondary UFC normalization. Overall response rate was $23 \%$ at 32.5 months (20).

Metabolic symptoms typically improve in responders $(14,20)$. Tumor size can decrease or remain stable (14) but residual tumor may be undetectable on repeat MRI; changes in tumor size may correlate with UFC response (15). However, reported rates of tumor shrinkage across studies remain low (Table $\mathbf{1}$ ).

Tumor features may not be useful in predicting response to cabergoline. In Pivonello's original cohort, all 6 of 10 who achieved complete or partial response showed D2R mRNA expression (8), but van der Pas et al. saw no differences in D2R mRNA or protein expression in their cohort of 33 (28). $\mathrm{D} 2 \mathrm{R}$ isoform expression may be more useful. In prolactinomas, the short isoform (D2S) regulates prolactin (PRL) synthesis and lactotroph proliferation while the long isoform (D2L) regulates PRL release (29). Consistent with the association between D2L overexpression and DA resistance $(29,30)$, the one nonresponder in Pivonello's study who expressed D2R harbored the long D2L isoform while 3 complete responders expressed D2S (8).

Given the low success rate of DA monotherapy in CD, Barbot et al. added ketoconazole in an attempt to improve therapeutic response. Fourteen patients with de novo or persistent/recurrent $\mathrm{CD}$ randomly assigned to cabergoline or ketoconazole monotherapy for 6 months were switched to combination therapy for 6-12 months if UFC and latenight salivary cortisol (LNSC) did not normalize despite escalated monotherapy doses. Complete response rate was 33\% with cabergoline monotherapy and 63\% with ketoconazole monotherapy; with the combination, 79\% achieved UFC normalization and clinical response persisted for at least 6 months (18). Those with persistent/recurrent disease were more likely to respond.

Pregnancy in women with CD is uncommon, but is associated with significant maternal and fetal morbidity (31). Surgical resection of the adenoma is the recommended treatment approach; steroidogenesis inhibitors are either contraindicated or indicated only if the risk to the fetus is outweighed by the 
TABLE 1 | Response to dopamine agonists in Cushing's disease.

\begin{tabular}{|c|c|c|c|c|c|}
\hline Study (Study type) & $N$ & Treatment duration & Tumor shrinkage $(n)$ & UFC response & АСТH response \\
\hline \multicolumn{6}{|l|}{ CAB TREATMENT } \\
\hline Pivonello et al. (8) (retrospective) & 10 & 3 months & $\mathrm{N} / \mathrm{A}$ & 4 complete response; 2 decreased & 6 decreased \\
\hline Godbout et al. (15) (retrospective) & 30 & 20-28 months & 1 & $11(36 \%)$ complete, 4 partial response & $\mathrm{N} / \mathrm{A}$ \\
\hline Barbot et al. (18) (prospective) & 6 & 12 months & $\mathrm{N} / \mathrm{A}$ & 2 complete, 1 partial response & No change \\
\hline Burman et al. (19) (prospective) & 24 & 1.5 months & $\mathrm{N} / \mathrm{A}$ & 2 complete, 3 partial response (>50\% decrease) & 6 decreased \\
\hline Ferriere et al. (20) (retrospective) & 53 & 3-105 months & $\mathrm{N} / \mathrm{A}$ & $\begin{array}{l}21 \text { complete, } 4 \text { partial response } \\
\text { Long term: } 12 \text { complete response }\end{array}$ & $\begin{array}{l}\text { Decreased in complete } \\
\text { responders }\end{array}$ \\
\hline Total for CAB & 175 & & $5 / 50(10 \%)$ & $\begin{array}{l}\text { 56/175 (32\%) complete response } \\
28 / 175 \text { (16\%) decreased }\end{array}$ & \\
\hline Lamberts et al. (22) & 13 & One dose & & 6 decreased & 6 decreased \\
\hline Boscaro et al. (23) & 6 & 2 days & & & 2 decreased \\
\hline Koppeschaar et al. (24) & 13 & One dose & & 3 decreased (serum cortisol) & \\
\hline Mercado-Asis et al. (25) & 6 & Up to 36 months & 1 & 1 complete response, 3 decreased & \\
\hline Invitti et al. (26) & 6 & 3 months & 1 & No change & No change \\
\hline Total for BRC & 49 & & $2 / 49(4 \%)$ & $\begin{array}{l}1 / 49(2 \%) \text { complete response } \\
12 / 49(24 \%) \text { decreased }\end{array}$ & \\
\hline Total overall & 224 & & 7/99 (7\%) & $\begin{array}{l}\text { 57/224 (25\%) complete response } \\
40 / 224(18 \%) \text { decreased }\end{array}$ & \\
\hline
\end{tabular}

Case series $\geq 5$ patients and clinical studies included.

ACTH, adrenocorticotropic hormone; BRC, bromocriptine; CAB, cabergoline; N/A, data not available; UFC, urinary free cortisol.

risks of nontreatment (32). Case reports suggest that cabergoline $2 \mathrm{mg} /$ week to $5 \mathrm{mg} /$ week might be an option for pregnant women with recurrent disease $(33,34)$, with patients demonstrating UFC normalization and no fetal complications. Of note, one patient required dose escalation up to $5 \mathrm{mg}$ twice weekly to control hypercortisolism by delivery.

Use of high-dose cabergoline in Parkinson's disease has been associated with increased risk for cardiac valvular abnormalities (35). It is recognized that cabergoline doses used for the treatment of pituitary tumors are an order of magnitude lower than those used in Parkinson's disease. Although the cabergolineassociated risk for developing valvular abnormalities has not been specifically studied in patients with $\mathrm{CD}$, treatment of patients with acromegaly or prolactinomas with standard doses, as well as the cumulative dose with long-term follow up, has not been associated with increased valvulopathy $(36,37)$.

Strong support for use of DA in CD is lacking (32), despite recent data showing clinical benefit (Table 1). If considered, its limitations should be acknowledged, as the clinical response is widely variable and maintaining consistent results is challenging (13). As the majority of studies were performed with cabergoline (Table 1), use of DA in CD should likely be limited to cabergoline.

\section{ACROMEGALY}

\section{Preclinical Studies}

Preclinical data strongly support targeting D2R in acromegaly. Dopamine receptor sites in human growth hormone $(\mathrm{GH})$ secreting adenomas have been identified (38, 39), and heterodimerization of $\mathrm{D} 2 \mathrm{R}$ and somatostatin receptor 5 (SSTR5) forms a Gi protein-linked effector complex (40) that may enhance functional activity, with interaction between the receptor/beta-arrestin complexes of the two receptor families affecting signaling and trafficking of activated receptors (41).

GH-secreting tumors commonly express D2R (9, 10, 42, 43), albeit at levels lower than those in normal pituitary (44). DA treatment of cultured somatotropinomas suppresses GH secretion by $20-25 \%$ or more (45-47), while tumors lacking D2R expression show resistance (48). However, as D2R expression positively correlated with in vitro but not in vivo suppression of $\mathrm{GH}$ by quinagolide in 24 somatotroph adenomas (47), the link between D2R expression and treatment response is unclear.

It is possible that D2R isoforms confer differential sensitivity to DA in GH-secreting adenomas. Treatment of GH-secreting murine GH3 cells with nerve growth factor promoted D2R 
expression, with preferential increase in D2S $(29,30)$. Exposure of these cells to bromocriptine resulted in decreased cell survival compared with GH3 cells treated with bromocriptine alone (49). Also, bromocriptine treatment of adenovirus D2S-transfected GH3 xenografts in nude mice significantly inhibited tumor growth compared with vector-transfected GH3 cells (50), suggesting that the ratio of D2S to D2L may influence DA inhibition of cell proliferation in $\mathrm{GH}$-secreting tumors.

Co-treating cultures of GH-secreting adenomas with somatostatin receptor ligands (SRL) and DA may be beneficial (51), due, at least in part, to heterogeneous SSTR subtype expression in different tumors and to variable expression levels of D2R and SSTR2/5 $(44,46)$. Rat pituitary somatomammotrophs strongly coexpressing GH and PRL show high D2R mRNA expression and undergo pronounced GH suppression by bromocriptine (48). However, whether tailoring treatment according to tumor phenotype and/or receptor expression may improve treatment responses is unknown.

\section{Clinical Efficacy}

Bromocriptine was the first effective medical therapy for biochemically uncontrolled acromegaly after surgery, but results are modest. Insulin-like growth factor (IGF)-I normalization and tumor size reduction is observed in only $10 \%$ and $<20 \%$ of patients, respectively, despite a GH reduction in $50 \%$ of patients. Quinagolide showed slightly better outcomes, with normalization of GH and IGF-I in 30\% of patients (52).
Cabergoline has been more widely studied, and was also proven effective in acromegaly (53). The largest prospective study of cabergoline monotherapy in acromegaly treated 64 patients for 3-40 months and yielded IGF-I normalization in $39 \%$. Patients with GH/PRL-secreting adenomas showed 50\% IGF-I normalization, and tumor shrinkage was observed in 13 of 21 patients with macroadenomas (54).

Chanson's meta-analysis of 20 studies showed moderate effects of cabergoline on both tumor size and GH/IGF-I response at doses ranging from 0.3 to $7 \mathrm{mg} /$ week $(37,55)$. Approximately one-third of patients experienced tumor shrinkage and IGFI normalization was achieved in $34 \%$ of 149 patients treated with cabergoline monotherapy. In five studies encompassing 77 patients uncontrolled with ongoing SRL treatment, the addition of cabergoline normalized IGF-I in 52\%. Benefit was mostly limited to patients with moderately increased (1.5 $\times$ ULN) baseline IGF-I levels (55). Their updated analysis including 4 additional combination therapy trials reported similar outcomes (37).

Data from the UK Acromegaly Register confirm that DA monotherapy is only moderately successful. Approximately $40 \%$ of 1792 patients received DA as monotherapy or in combination with SRL, with cabergoline most commonly delivered in doses of $0.5 \mathrm{mg}$ twice weekly, $1 \mathrm{mg}$ twice weekly, and $0.5 \mathrm{mg}$ daily; normalization of both GH and IGF-I was seen in $26 \%$ on DA monotherapy and $20 \%$ of patients on combination therapy. As patients treated with combination therapy presumably failed prior monotherapy, lower response rates might be expected, yet

TABLE 2 | Response to dopamine agonists in NFPT.

\begin{tabular}{|c|c|c|c|c|c|c|}
\hline Study & $N$ & Mean follow-up (months) & Therapy & Tumor shrinkage $(n)$ & Tumor growth $(n)$ & Stable disease $(n)$ \\
\hline Wollesen et al. (88) & 11 & $2-33$ & $\mathrm{BRC}$ & 9 & 0 & 2 \\
\hline Barrow et al. (75) & 12 & 1.5 & $\mathrm{BRC}$ & 6 & 0 & 6 \\
\hline Grossman et al. (76) & 15 & $3-36$ & $\mathrm{DA}$ & 0 & 0 & 15 \\
\hline Verde et al. (78) & 20 & $1-32$ & $\mathrm{BRC}$ & 1 & 0 & 19 \\
\hline Zarate et al. (79) & 7 & $0.5-12$ & $\mathrm{BRC}$ & 0 & 0 & 7 \\
\hline Bevan et al. (80) & 8 & $4-12$ & $\mathrm{BRC}$ & 0 & 0 & 8 \\
\hline $\begin{array}{l}\text { van Schaardenburg et } \\
\text { al. (81) }\end{array}$ & 25 & 18 & $\mathrm{BRC}$ & 4 & 1 & 20 \\
\hline Ferone et al. (72) & 6 & $6-12$ & Quinagolide & 2 & 0 & 4 \\
\hline $\begin{array}{l}\text { Kwekkeboom et al. } \\
\text { (65) }\end{array}$ & 5 & 12 & Quinagolide & 1 & 0 & 4 \\
\hline Nobels et al. (83) & 10 & $36-93$ & Quinagolide & 0 & 6 & 4 \\
\hline Colao et al. (74) & 10 & & DA & 2 & 0 & 8 \\
\hline Lohmann et al. (89) & 13 & 12 & $\mathrm{CAB}$ & 7 & 0 & 6 \\
\hline Pivonello et al. (27) & 9 & 12 & $\mathrm{CAB}$ & 5 & 3 & 1 \\
\hline Garcia et al. (90) & 19 & 6 & $\mathrm{CAB}$ & 6 & 4 & 9 \\
\hline Viera Neto et al. (84) & 9 & 6 & CAB & 6 & 0 & 3 \\
\hline Greenman et al. (86) & 79 & 105 & $\mathrm{CAB}$ & 28 & 17 & 34 \\
\hline Total & 258 & & & $77 / 258$ (30\%) & $31 / 258$ (12\%) & 150/258 (58\%) \\
\hline Total for BRC & 83 & & & 20/83 (24\%) & $1 / 83(1 \%)$ & $62 / 83(75 \%)$ \\
\hline Total for CAB & 154 & & & $54 / 154$ (35\%) & 24/154 (16\%) & 76/154 (49\%) \\
\hline Total for Quinagolide & 21 & & & $3 / 21(14 \%)$ & 6/21 (29\%) & $12 / 21$ (57\%) \\
\hline
\end{tabular}

BRC, bromocriptine; $C A B$, cabergoline; DA, dopamine agonist; NFPT, nonfunctioning pituitary tumor. 
success was still more likely in patients with only moderately elevated pretreatment GH levels (56).

Data from the Bulgarian Acromegaly Database of 534 patients showed similar GH/IGF-I responses, but prior radiation therapy predicted better outcomes. Among non-irradiated patients, 16\% and $18 \%$ of those treated with bromocriptine or cabergoline, respectively, achieved disease control; among those previously irradiated, one-third were controlled after a median of 10 years (57).

Few data are available on the combination of cabergoline and pegvisomant (58-60). Cross-sectional studies show significantly decreased IGF-I with long-term combination treatment in patients with mildly elevated IGF-I despite pegvisomant monotherapy (60). In a prospective trial of this combination, of 24 patients with elevated IGF-I who were treatment-naïve or previously treated with DA or SRL monotherapy, $68 \%$ achieved IGF-I normalization on escalating doses of cabergoline (up to $0.5 \mathrm{mg} /$ day) given for 18 weeks plus pegvisomant 10 $\mathrm{mg} /$ day for 12 additional weeks. After switching to pegvisomant monotherapy $(10 \mathrm{mg} /$ day $)$ for another 12 weeks, only $26 \%$ remained controlled (59). Two patients achieved control with cabergoline monotherapy, one with moderately elevated IGFI $(1.3 \times \mathrm{ULN})$ and the other with a GH/PRL-secreting tumor, supporting prior data that these factors likely influence response to DA therapy.

Current guidelines recommend cabergoline as first-line medical therapy for patients with mild IGF-I elevations after surgical adenoma resection (61), and as an add-on to SRL in patients with inadequate biochemical control on SRL monotherapy $(61,62)$. As bromocriptine is less effective and confers more adverse events than does cabergoline $(63,64)$, its use in acromegaly is limited.

\section{NONFUNCTIONING PITUITARY TUMORS}

\section{Preclinical Studies}

As there are no good laboratory models of NFPT, preclinical data are limited to primary tumor cultures from surgical samples.

Most NFPT express D2R $(3,9,44)$, and DA has been shown to reduce gonadotropin secretion (65) and inhibit thymidine incorporation in vitro (66). D2R mRNA expression is higher in gonadotroph and null-cell NFPT compared with plurihormonal and silent corticotroph adenomas $(67,68)$, although D2L/D2S ratios tend to be similar among the histological types (69). NFPT show higher D2R mRNA expression levels compared with somatotroph adenomas, but lower expression compared with normal pituitaries (44) and significantly lower compared with prolactinomas (69). High D2R protein expression levels were found in 26 of 70 NFPT, 26 of 28 prolactinomas, and 18 of $20 \mathrm{GH}$-secreting adenomas, as well as 31 of $37 \mathrm{FSH}$-secreting adenomas, 18 of 27 ACTH-secreting adenomas, and 9 of 15 thyrotropinomas (9).

NFPT also express SSTRs (51), but its significance is unclear. Some have shown a positive correlation between mRNA expression of D2R and SSTR2/3 and an inverse correlation with SSTR1/5 (68), while others found no correlation at all (44).
Tumoral D2R abundance may correlate with clinical response to DA treatment (70-74), so scintigraphy using radiolabeled D2R ligands may be useful in identifying tumors likely to respond to DA. In addition, NFPT expressing short D2S show a good response to DA therapy $(3,27)$. Study of tumor tissue showed D2R mRNA expression in 12 of 18 samples: 6 had only the D2L isoform, 2 had only the D2S isoform, and 4 expressed both. Nine of these patients with residual tumors after surgery were treated with cabergoline for 1 year, and tumor shrinkage was observed in 5 , but the small number of patients precluded a firm conclusion regarding correlation between D2S expression and DA treatment response (27).

\section{Clinical Efficacy}

Patients with NFPT typically lack serum markers reflecting tumor proliferation, so treatment efficacy is based on tumor size assessment.

In pooled studies through 1992, bromocriptine induced tumor growth stabilization in 76 of 84 NFPT as measured on CT scan in patients with persistent disease (75-82). Nobels et al. saw similar results on CT/MRI in $10 \mathrm{NFPT}$ patients treated with quinagolide for a median of 57 months, with a $>10 \%$ tumor volume decrease in 3 patients and stable disease in another 3 patients, 2 of whom later saw a decrease in tumor volume on further follow-up (83).

Vieira Neto et al. studied 23 patients with postoperative residual tumors, 9 of whom were treated with cabergoline, starting at an initial dose of $0.5 \mathrm{mg}$ during the first week, and increased by $0.5 \mathrm{mg}$ per week up to $3.0 \mathrm{mg} /$ week, maintained for 6 months. $A \geq 25 \%$ tumor volume reduction was seen on MRI in 6 of 9 patients (median 29\%), and D2R expression was detected in all 6 tumors. Most of the untreated patients had stable disease (84).

Greenman et al. reported the largest series of NFPT patients treated with DA $(85,86)$. Treatment doses were gradually increased up to $10 \mathrm{mg} /$ day of bromocriptine and $2 \mathrm{mg} /$ week of cabergoline. The initial cohort consisted of 33 patients with postoperative residual tumors; 20 received immediate preventive treatment, while 13 were started on DA when tumor growth was noted. A separate cohort of 76 NFPT patients at the same institution served as controls. After a mean 40 months' follow up, $45 \%$ saw tumor mass shrinkage and $45 \%$ had stable disease with preventive treatment. With secondary treatment, $65 \%$ saw tumor shrinkage or stabilization; only $38 \%$ had stable disease in the control group (85).

The treatment cohort expanded to 114 patients, and 79 were evaluable: 55 received preventive DA treatment and 24 received treatment upon tumor growth. With preventive treatment, $87 \%$ achieved tumor control (38\% shrinkage, $49 \%$ stabilization); older age and smaller preoperative tumors were independently associated with a better response. With secondary treatment, 58\% achieved tumor control (29\% shrinkage), while only $47 \%$ had stable disease among controls. Median tumor progression-free survival was 6 years for controls and 8.5 years in the secondary treatment group, but was not reached in the preventive treatment group by year 24 . The estimated 5-year progression-free survival rate was $88 \%$ with 
preventive treatment, $60 \%$ with secondary treatment, and $69 \%$ in controls. At 15 years, the rate remained high at $81 \%$ with preventive treatment, but fell to $24 \%$ with secondary treatment, and to $4 \%$ in controls (86). Fewer patients in the preventive treatment group required additional surgery or radiotherapy.

D2R staining was diffusely positive in half of tumors tested across both treatment groups, and short D2S mRNA isoform was more frequently detected. However, none of these features correlated with treatment response (86).

Pooled data on 199 patients in published cases and series found that $28 \%$ of DA-treated NFPT patients had reduced tumor size, $64 \%$ had stable disease, and only $8.5 \%$ experienced tumor growth (87). Updated data including more recent series indicate that $58 \%$ show stable disease and $30 \%$ show tumor shrinkage (Table 2).

DA therapy is not routinely recommended for patients with persistent/recurrent NFPT due to insufficient evidence $(91,92)$. The emergence of recent data (86) may prompt a revisiting of this question, but further study is still required to identify the optimal use of this treatment in different clinical scenarios.

\section{REFERENCES}

1. Ferone D, Gatto F, Arvigo M, Resmini E, Boschetti M, Teti C, et al. The clinical-molecular interface of somatostatin, dopamine and their receptors in pituitary pathophysiology. J Mol Endocrinol. (2009) 42:361-70. doi: 10.1677/JME-08-0162

2. Melmed S, Casanueva FF, Hoffman AR, Kleinberg DL, Montori VM, Schlechte JA, et al. Diagnosis and treatment of hyperprolactinemia: an Endocrine Society clinical practice guideline. J Clin Endocrinol Metab. (2011) 96:273-88. doi: 10.1210/jc.2010-1692

3. Renner U, Arzberger T, Pagotto U, Leimgruber S, Uhl E, Muller A, et al. Heterogeneous dopamine D2 receptor subtype messenger ribonucleic acid expression in clinically nonfunctioning pituitary adenomas. J Clin Endocrinol Metab. (1998) 83:1368-75. doi: 10.1210/jcem.83.4.4685

4. Farah JM Jr, Malcolm DS, Mueller GP. Dopaminergic inhibition of pituitary beta-endorphin-like immunoreactivity secretion in the rat. Endocrinology (1982) 110:657-9. doi: 10.1210/endo-110-2-657

5. Farrell WE, Clark AJ, Stewart MF, Crosby SR, White A. Bromocriptine inhibits pro-opiomelanocortin mRNA and ACTH precursor secretion in small cell lung cancer cell lines. J Clin Invest. (1992) 90:705-10. doi: 10.1172/JCI115941

6. Yin D, Kondo S, Takeuchi J, Morimura T. Induction of apoptosis in murine ACTH-secreting pituitary adenoma cells by bromocriptine. FEBS Lett. (1994) 339:73-5. doi: 10.1016/0014-5793(94)80387-0

7. de Bruin C, Hanson JM, Meij BP, Kooistra HS, Waaijers AM, Uitterlinden $\mathrm{P}$, et al. Expression and functional analysis of dopamine receptor subtype 2 and somatostatin receptor subtypes in canine cushing's disease. Endocrinology (2008) 149:4357-66. doi: 10.1210/en.2008-0244

8. Pivonello R, Ferone D, de Herder WW, Kros JM, De Caro ML, Arvigo M, et al. Dopamine receptor expression and function in corticotroph pituitary tumors. J Clin Endocrinol Metab. (2004) 89:2452-62. doi: 10.1210/jc.2003-030837

9. Wang Y, Li J, Tohti M, Hu Y, Wang S, Li W, et al. The expression profile of Dopamine D2 receptor, MGMT and VEGF in different histological subtypes of pituitary adenomas: a study of 197 cases and indications for the medical therapy. J Exp Clin Cancer Res. (2014) 33:56. doi: 10.1186/s13046-014-0056-y

10. Stefaneanu L, Kovacs K, Horvath E, Buchfelder M, Fahlbusch R, Lancranjan L. Dopamine D2 receptor gene expression in human adenohypophysial adenomas. Endocrine (2001) 14:329-36. doi: 10.1385/ENDO:14:3:329

11. Tateno $\mathrm{T}$, Kato M, Tani Y, Oyama K, Yamada S, Hirata Y. Differential expression of somatostatin and dopamine receptor subtype genes in adrenocorticotropin (ACTH)-secreting pituitary

\section{CONCLUSIONS}

DA are the first-line treatment for prolactinomas. The presence of $\mathrm{D} 2 \mathrm{R}$ in all pituitary cell types, data from in vitro studies, and clinical data suggest DA may also be an effective primary or second-line treatment for some patients with $\mathrm{CD}$, and as second-line therapy in selected patients with persistent/recurrent acromegaly or NFPT.

\section{AUTHOR CONTRIBUTIONS}

OC and YG conceived and designed the project. OC collected and analyzed the evidence and prepared the draft manuscript. OC and YG contributed to manuscript revisions and approved the submitted version.

\section{FUNDING}

This work was supported by NIH grant R21 DK105405 (OC). The funding source had no role in study design, data analysis, or decision to publish.

tumors and silent corticotroph adenomas. Endocr J. (2009) 56:579-84. doi: 10.1507/endocrj.K08E-186

12. de Bruin C, Pereira AM, Feelders RA, Romijn JA, Roelfsema F, Sprij-Mooij $\mathrm{DM}$, et al. Coexpression of dopamine and somatostatin receptor subtypes in corticotroph adenomas. J Clin Endocrinol Metab. (2009) 94:1118-24. doi: 10.1210/jc.2008-2101

13. Pivonello R, De Leo M, Cozzolino A, Colao A. The Treatment of Cushing's Disease. Endocr Rev. (2015) 36:385-486. doi: 10.1210/er.2013-1048

14. Pivonello R, De Martino MC, Cappabianca P, De Leo M, Faggiano A, Lombardi G, et al. The medical treatment of Cushing's disease: effectiveness of chronic treatment with the dopamine agonist cabergoline in patients unsuccessfully treated by surgery. J Clin Endocrinol Metab. (2009) 94:223-30. doi: $10.1210 /$ jc.2008-1533

15. Godbout A, Manavela M, Danilowicz K, Beauregard H, Bruno OD, Lacroix A. Cabergoline monotherapy in the long-term treatment of Cushing's disease. Eur J Endocrinol. (2010) 163:709-16. doi: 10.1530/EJE-10-0382

16. Lila AR, Gopal RA, Acharya SV, George J, Sarathi V, Bandgar T, et al. Efficacy of cabergoline in uncured (persistent or recurrent) Cushing disease after pituitary surgical treatment with or without radiotherapy. Endocr Pract. (2010) 16:968-76. doi: 10.4158/EP10031.OR

17. Vilar L, Naves LA, Azevedo MF, Arruda MJ, Arahata CM, Moura ESL, et al. Effectiveness of cabergoline in monotherapy and combined with ketoconazole in the management of Cushing's disease. Pituitary (2010) 13:123-9. doi: 10.1007/s11102-009-0209-8

18. Barbot M, Albiger N, Ceccato F, Zilio M, Frigo AC, Denaro L, et al. Combination therapy for Cushing's disease: effectiveness of two schedules of treatment: should we start with cabergoline or ketoconazole? Pituitary (2014) 17:109-17. doi: 10.1007/s11102-013-0475-3

19. Burman P, Eden-Engstrom B, Ekman B, Karlsson FA, Schwarcz E, Wahlberg J. Limited value of cabergoline in Cushing's disease: a prospective study of a 6-week treatment in 20 patients. Eur J Endocrinol. (2016) 174:17-24. doi: 10.1530/EJE-15-0807

20. Ferriere A, Cortet C, Chanson P, Delemer B, Caron P, Chabre O, et al. Cabergoline for Cushing's disease: a large retrospective multicenter study. Eur J Endocrinol. (2017) 176:305-14. doi: 10.1530/EJE-16-0662

21. Kennedy AL, Sheridan B, Montgomery DA. ACTH and cortisol response to bromocriptine, and results of long-term therapy, in Cushing's disease. Acta Endocrinol. (1978) 89:461-8.

22. Lamberts SW, Klijn JG, de Quijada M, Timmermans HA, Uitterlinden $\mathrm{P}$, de Jong $\mathrm{FH}$, et al. The mechanism of the suppressive action of 
bromocriptine on adrenocorticotropin secretion in patients with Cushing's disease and Nelson's syndrome. J Clin Endocrinol Metab. (1980) 51:307-11. doi: 10.1210/jcem-51-2-307

23. Boscaro M, Benato M, Mantero F. Effect of bromocriptine in pituitarydependent Cushing's syndrome. Clin Endocrinol. (1983) 19:485-91.

24. Koppeschaar HP, Croughs RJ, Thijssen JH, Schwarz F. Response to neurotransmitter modulating drugs in patients with Cushing's disease. Clin Endocrinol. (1986) 25:661-7.

25. Mercado-Asis LB, Yasuda K, Murayama M, Mune T, Morita H, Miura K. Beneficial effects of high daily dose bromocriptine treatment in Cushing's disease. Endocrinol Jpn. (1992) 39:385-95.

26. Invitti C, De Martin M, Danesi L, Cavagnini F. Effect of injectable bromocriptine in patients with Cushing's disease. Exp Clin Endocrinol Diabetes (1995) 103:266-71. doi: 10.1055/s-0029-1211361

27. Pivonello R, Matrone C, Filippella M, Cavallo LM, Di Somma C, Cappabianca P, et al. Dopamine receptor expression and function in clinically nonfunctioning pituitary tumors: comparison with the effectiveness of cabergoline treatment. $J$ Clin Endocrinol Metab. (2004) 89:1674-83. doi: 10.1210/jc.2003030859

28. van der Pas R, Feelders RA, Gatto F, de Bruin C, Pereira AM, van Koetsveld PM, et al. Preoperative normalization of cortisol levels in Cushing's disease after medical treatment: consequences for somatostatin and dopamine receptor subtype expression and in vitro response to somatostatin analogs and dopamine agonists. J Clin Endocrinol Metab. (2013) 98:E1880-90. doi: 10.1210/jc.2013-1987

29. Iaccarino C, Samad TA, Mathis C, Kercret H, Picetti R, Borrelli E. Control of lactotrop proliferation by dopamine: essential role of signaling through D2 receptors and ERKs. Proc Natl Acad Sci USA. (2002) 99:14530-5. doi: 10.1073/pnas.222319599

30. Wu ZB, Zheng WM, Su ZP, Chen Y, Wu JS, Wang CD, et al. Expression of D2RmRNA isoforms and ERmRNA isoforms in prolactinomas: correlation with the response to bromocriptine and with tumor biological behavior. J Neurooncol. (2010) 99:25-32. doi: 10.1007/s11060-0090107-y

31. Lindsay JR, Jonklaas J, Oldfield EH, Nieman LK. Cushing's syndrome during pregnancy: personal experience and review of the literature. J Clin Endocrinol Metab. (2005) 90:3077-83. doi: 10.1210/jc.2004-2361

32. Biller BM, Grossman AB, Stewart PM, Melmed S, Bertagna X, Bertherat J, et al. Treatment of adrenocorticotropin-dependent Cushing's syndrome: a consensus statement. J Clin Endocrinol Metab. (2008) 93:2454-62. doi: $10.1210 /$ jc. $2007-2734$

33. Woo I, Ehsanipoor RM. Cabergoline therapy for Cushing disease throughout pregnancy. Obstet Gynecol. (2013) $122(2 \mathrm{Pt}$ 2):485-7. doi: 10.1097/AOG.0b013e31829e398a

34. Nakhleh A, Saiegh L, Reut M, Ahmad MS, Pearl IW, Shechner C. Cabergoline treatment for recurrent Cushing's disease during pregnancy. Hormones (2016) 15:453-8. doi: 10.14310/horm.2002.1685

35. Zanettini R, Antonini A, Gatto G, Gentile R, Tesei S, Pezzoli G. Valvular heart disease and the use of dopamine agonists for Parkinson's disease. N Engl J Med. (2007) 356:39-46. doi: 10.1056/NEJMoa054830

36. Auriemma RS, Pivonello R, Ferreri L, Priscitelli P, Colao A. Cabergoline use for pituitary tumors and valvular disorders. Endocrinol Metab Clin North Am. (2015) 44:89-97. doi: 10.1016/j.ecl.2014.10.007

37. Kuhn E, Chanson P. Cabergoline in acromegaly. Pituitary (2017) 20:121-8. doi: 10.1007/s11102-016-0782-6

38. Bression D, Brandi AM, Nousbaum A, Le Dafniet M, Racadot J, Peillon F. Evidence of dopamine receptors in human growth hormone (GH)secreting adenomas with concomitant study of dopamine inhibition of GH secretion in a perifusion system. J Clin Endocrinol Metab. (1982) 55:589-93. doi: 10.1210/jcem-55-3-589

39. Koga M, Nakao H, Arao M, Sato B, Noma K, Morimoto $Y$, et al. Demonstration of specific dopamine receptors on human pituitary adenomas. Acta Endocrinol. (1987) 114:595-602.

40. Rocheville M, Lange DC, Kumar U, Patel SC, Patel RC, Patel YC. Receptors for dopamine and somatostatin: formation of heterooligomers with enhanced functional activity. Science (2000) 288:154-7. doi: $10.1126 /$ science. 288.5463 .154
41. Gatto F, Hofland LJ. The role of somatostatin and dopamine D2 retceptors in endocrine tumors. Endocr Relat Cancer (2011) 18:R233-251. doi: 10.1530/ERC-10-0334

42. Zatelli MC, Piccin D, Tagliati F, Bottoni A, Ambrosio MR, Margutti $A$, et al. Dopamine receptor subtype 2 and somatostatin receptor subtype 5 expression influences somatostatin analogs effects on human somatotroph pituitary adenomas in vitro. J Mol Endocrinol. (2005) 35:333-41. doi: 10.1677/jme.1.01876

43. Pawlikowski M. Immunohistochemical detection of dopamine D2 receptors in human pituitary adenomas. Folia Histochem Cytobiol. (2010) 48:394-7. doi: 10.2478/v10042-010-0031-1

44. Neto LV, Machado Ede O, Luque RM, Taboada GF, Marcondes JB, Chimelli LM, et al. Expression analysis of dopamine receptor subtypes in normal human pituitaries, nonfunctioning pituitary adenomas and somatotropinomas, and the association between dopamine and somatostatin receptors with clinical response to octreotide-LAR in acromegaly. J Clin Endocrinol Metab. (2009) 94:1931-7. doi: 10.1210/jc.2008-1826

45. Peillon F, Cesselin F, Bression D, Zygelman N, Brandi AM, Nousbaum A, et al. In vitro effect of dopamine and L-dopa on prolactin and growth hormone release from human pituitary adenomas. J Clin Endocrinol Metab. (1979) 49:737-41. doi: 10.1210/jcem-49-5-737

46. Saveanu A, Gunz G, Guillen S, Dufour H, Culler MD, Jaquet P. Somatostatin and dopamine-somatostatin multiple ligands directed towards somatostatin and dopamine receptors in pituitary adenomas. Neuroendocrinology (2006) 83:258-63. doi: 10.1159/000095536

47. Ferone D, de Herder WW, Pivonello R, Kros JM, van Koetsveld PM, de Jong T, et al. Correlation of in vitro and in vivo somatotropic adenoma responsiveness to somatostatin analogs and dopamine agonists with immunohistochemical evaluation of somatostatin and dopamine receptors and electron microscopy. J Clin Endocrinol Metab. (2008) 93:1412-7. doi: 10.1210/jc.2007-1358

48. Trouillas J, Chevallier P, Remy C, Rajas F, Cohen R, Calle A, et al. Differential actions of the dopamine agonist bromocriptine on growth of SMtTW tumors exhibiting a prolactin and/or a somatotroph cell phenotype: relation to dopamine D2 receptor expression. Endocrinology (1999) 140:1321. doi: 10.1210/endo.140.1.6450

49. Su Z, Jiang X, Wang C, Liu J, Chen Y, Li Q, et al. Differential effects of nerve growth factor on expression of dopamine 2 receptor subtypes in GH3 rat pituitary tumor cells. Endocrine (2012) 42:670-5. doi: 10.1007/s12020-012-9715-y

50. Li Q, Su Z, Liu J, Cai L, Lu J, Lin S, et al. Dopamine receptor D2S gene transfer improves the sensitivity of $\mathrm{GH} 3$ rat pituitary adenoma cells to bromocriptine. Mol Cell Endocrinol. (2014) 382:377-84. doi: 10.1016/j.mce.2013. 10.021

51. Saveanu A, Jaquet P, Brue T, Barlier A. Relevance of coexpression of somatostatin and dopamine D2 receptors in pituitary adenomas. Mol Cell Endocrinol. (2008) 286:206-13. doi: 10.1016/j.mce.2007.12.008

52. Colao A, Filippella M, Pivonello R, Di Somma C, Faggiano A, Lombardi G. Combined therapy of somatostatin analogues and dopamine agonists in the treatment of pituitary tumours. Eur J Endocrinol. (2007) 156(Suppl. 1):S57-63. doi: $10.1530 /$ eje. 1.02348

53. Marazuela M, Ramos-Levi A, Sampedro-Nunez M, Bernabeu I. Cabergoline treatment in acromegaly: pros. Endocrine (2014) 46:215-9. doi: 10.1007/s12020-014-0206-1

54. Abs R, Verhelst J, Maiter D, Van Acker K, Nobels F, Coolens JL, et al. Cabergoline in the treatment of acromegaly: a study in 64 patients. J Clin Endocrinol Metab. (1998) 83:374-8. doi: 10.1210/jcem.83.2.4556

55. Sandret L, Maison P, Chanson P. Place of cabergoline in acromegaly: a meta-analysis. J Clin Endocrinol Metab. (2011) 96:1327-35. doi: $10.1210 /$ jc.2010-2443

56. Howlett TA, Willis D, Walker G, Wass JA, Trainer PJ. Control of growth hormone and IGF1 in patients with acromegaly in the UK: responses to medical treatment with somatostatin analogues and dopamine agonists. Clin Endocrinol. (2013) 79:689-99. doi: 10.1111/cen.12207

57. Vandeva S, Elenkova A, Natchev E, Kirilov G, Tcharaktchiev D, Yaneva M, et al. Treatment outcome results from the Bulgarian Acromegaly Database: adjuvant dopamine agonist therapy is efficient in less than one fifth of non-irradiated patients. Exp Clin Endocrinol Diabetes (2015) 123:66-71. doi: $10.1055 / \mathrm{s}-0034-1389987$ 
58. Roemmler J, Steffin B, Gutt B, Schneider HJ, Sievers C, Bidlingmaier M, et al. The acute effect of a single application of cabergoline on endogenous GH levels in patients with acromegaly on pegvisomant treatment. Growth Horm IGF Res. (2010) 20:338-44. doi: 10.1016/j.ghir.2010.05.004

59. Higham CE, Atkinson AB, Aylwin S, Bidlingmaier M, Drake WM, Lewis $A$, et al. Effective combination treatment with cabergoline and low-dose pegvisomant in active acromegaly: a prospective clinical trial. J Clin Endocrinol Metab. (2012) 97:1187-93. doi: 10.1210/jc.2011-2603

60. Bernabeu I, Alvarez-Escola C, Paniagua AE, Lucas T, Pavon I, CabezasAgricola JM, et al. Pegvisomant and cabergoline combination therapy in acromegaly. Pituitary (2013) 16:101-8. doi: 10.1007/s11102-012-0382-z

61. Melmed S, Bronstein MD, Chanson P, Klibanski A, Casanueva FF, Wass JAH, et al. A Consensus Statement on acromegaly therapeutic outcomes. Nat Rev Endocrinol. (2018) doi: 10.1038/s41574-018-0058-5. [Epub ahead of print].

62. Katznelson L, Laws ERJr, Melmed S, Molitch ME, Murad MH, Utz A, et al. Acromegaly: an endocrine society clinical practice guideline. J Clin Endocrinol Metab. (2014) 99:3933-51. doi: 10.1210/jc.2014-2700

63. Lindholm J, Riishede J, Vestergaard S, Hummer L, Faber O, Hagen C. No effect of bromocriptine in acromegaly: a controlled trial. N Engl J Med. (1981) 304:1450-4. doi: 10.1056/NEJM198106113042402

64. Jaffe CA, Barkan AL. Treatment of acromegaly with dopamine agonists. Endocrinol Metab Clin North Am. (1992) 21:713-35.

65. Kwekkeboom DJ, Hofland LJ, van Koetsveld PM, Singh R, van den Berge JH, Lamberts SW. Bromocriptine increasingly suppresses the in vitro gonadotropin and alpha-subunit release from pituitary adenomas during long term culture. J Clin Endocrinol Metab. (1990) 71:718-24. doi: 10.1210/jcem-71-3-718

66. Florio T, Barbieri F, Spaziante R, Zona G, Hofland LJ, van Koetsveld PM, et al. Efficacy of a dopamine-somatostatin chimeric molecule, BIM-23A760, in the control of cell growth from primary cultures of human non-functioning pituitary adenomas: a multi-center study. Endocr Relat Cancer (2008) 15:58396. doi: 10.1677/ERC-07-0271

67. Gabalec F, Beranek M, Netuka D, Masopust V, Nahlovsky J, Cesak T, et al. Dopamine 2 receptor expression in various pathological types of clinically non-functioning pituitary adenomas. Pituitary (2012) 15:222-6. doi: 10.1007/s11102-011-0316-1

68. Gabalec F, Drastikova M, Cesak T, Netuka D, Masopust V, Machac J, et al. Dopamine 2 and somatostatin 1-5 receptors coexpression in clinically nonfunctioning pituitary adenomas. Physiol Res. (2015) 64:369-77.

69. Su Z, Wang C, Wu J, Jiang X, Chen Y, Chen Y, et al. Expression of dopamine 2 receptor subtype mRNA in clinically nonfunctioning pituitary adenomas. Neurol Sci. (2012) 33:275-9. doi: 10.1007/s10072-011-0701-6

70. Bevan JS, Burke CW. Non-functioning pituitary adenomas do not regress during bromocriptine therapy but possess membrane-bound dopamine receptors which bind bromocriptine. Clin Endocrinol. (1986) 25:561-72.

71. Pirker W, Riedl M, Luger A, Czech T, Rossler K, Asenbaum S, et al. Dopamine D2 receptor imaging in pituitary adenomas using iodine-123-epidepride and SPECT. J Nucl Med. (1996) 37:1931-7.

72. Ferone D, Lastoria S, Colao A, Varrella P, Cerbone G, Acampa W, et al. Correlation of scintigraphic results using 123I-methoxybenzamide with hormone levels and tumor size response to quinagolide in patients with pituitary adenomas. J Clin Endocrinol Metab. (1998) 83:248-52. doi: $10.1210 /$ jcem.83.1.4493

73. de Herder WW, Reijs AE, de Swart J, Kaandorp Y, Lamberts SW, Krenning EP, et al. Comparison of iodine-123 epidepride and iodine-123 IBZM for dopamine D2 receptor imaging in clinically non-functioning pituitary macroadenomas and macroprolactinomas. Eur J Nucl Med. (1999) 26:46-50

74. Colao A, Ferone D, Lastoria S, Cerbone G, Di Sarno A, Di Somma $\mathrm{C}$, et al. Hormone levels and tumour size response to quinagolide and cabergoline in patients with prolactin-secreting and clinically nonfunctioning pituitary adenomas: predictive value of pituitary scintigraphy with 123I-methoxybenzamide. Clin Endocrinol. (2000) 52:437-45. doi: 10.1046/j.1365-2265.2000.00951.x

75. Barrow DL, Tindall GT, Kovacs K, Thorner MO, Horvath E, Hoffman JCJr. Clinical and pathological effects of bromocriptine on prolactinsecreting and other pituitary tumors. J Neurosurg. (1984) 60:1-7. doi: $10.3171 /$ jns.1984.60.1.0001
76. Grossman A, Ross R, Charlesworth M, Adams CB, Wass JA, Doniach I, et al. The effect of dopamine agonist therapy on large functionless pituitary tumours. Clin Endocrinol. (1985) 22:679-86.

77. Pullan PT, Carroll WM, Chakera TM, Khangure MS, Vaughan RJ. Management of extra-sellar pituitary tumours with bromocriptine: comparison of prolactin secreting and non-functioning tumours using half-field visual evoked potentials and computerised tomography. Aust N Z J Med. (1985) 15:203-8.

78. Verde G, Oppizzi G, Chiodini PG, Dallabonzana D, Luccarelli G, Liuzzi A. Effect of chronic bromocriptine administration on tumor size in patients with "nonsecreting" pituitary adenomas. J Endocrinol Invest. (1985) 8:113-5. doi: 10.1007/BF03350660

79. Zarate A, Moran C, Kleriga E, Loyo M, Gonzalez-Angulo A, Aquilar-Parada E. Bromocriptine therapy as pre-operative adjunct of non-functional pituitary macroadenomas. Acta Endocrinol. (1985) 108:445-50.

80. Bevan JS, Adams CB, Burke CW, Morton KE, Molyneux AJ, Moore RA, et al. Factors in the outcome of transsphenoidal surgery for prolactinoma and nonfunctioning pituitary tumour, including pre-operative bromocriptine therapy. Clin Endocrinol. (1987) 26:541-56.

81. van Schaardenburg D, Roelfsema F, van Seters AP, Vielvoye GJ. Bromocriptine therapy for non-functioning pituitary adenoma. Clin Endocrinol. (1989) 30:475-84.

82. Bevan JS, Webster J, Burke CW, Scanlon MF. Dopamine agonists and pituitary tumor shrinkage. Endocr Rev. (1992) 13:220-40. doi: 10.1210/edrv-13-2-220

83. Nobels FR, de Herder WW, van den Brink WM, Kwekkeboom DJ, Hofland LJ, Zuyderwijk J, et al. Long-term treatment with the dopamine agonist quinagolide of patients with clinically non-functioning pituitary adenoma. Eur J Endocrinol. (2000) 143:615-21. doi: 10.1530/eje.0.1430615

84. Vieira Neto L, Wildemberg LE, Moraes AB, Colli LM, Kasuki L, Marques $\mathrm{NV}$, et al. Dopamine receptor subtype 2 expression profile in nonfunctioning pituitary adenomas and in vivo response to cabergoline therapy. Clin Endocrinol. (2015) 82:739-46. doi: 10.1111/cen.12684

85. Greenman Y, Tordjman K, Osher E, Veshchev I, Shenkerman G, Reider GII, et al. Postoperative treatment of clinically nonfunctioning pituitary adenomas with dopamine agonists decreases tumour remnant growth. Clin Endocrinol. (2005) 63:39-44. doi: 10.1111/j.1365-2265.2005.02295.x

86. Greenman Y, Cooper O, Yaish I, Robenshtok E, Sagiv N, Jonas-Kimchi T, et al. Treatment of clinically nonfunctioning pituitary adenomas with dopamine agonists. Eur J Endocrinol. (2016) 175:63-72. doi: 10.1530/EJE-16-0206

87. Colao A, Di Somma C, Pivonello R, Faggiano A, Lombardi G, Savastano S. Medical therapy for clinically non-functioning pituitary adenomas. Endocr Relat Cancer (2008) 15:905-15. doi: 10.1677/ERC-08-0181

88. Wollesen F, Andersen T, Karle A. Size reduction of extrasellar pituitary tumors during bromocriptine treatment. Ann Intern Med. (1982) 96:281-6.

89. Lohmann T, Trantakis C, Biesold M, Prothmann S, Guenzel S, Schober R, et al. Minor tumour shrinkage in nonfunctioning pituitary adenomas by long-term treatment with the dopamine agonist cabergoline. Pituitary (2001) 4:173-8. doi: 10.1023/A:1015366923810

90. Garcia EC, Naves LA, Silva AO, de Castro LF, Casulari LA, Azevedo MF. Short-term treatment with cabergoline can lead to tumor shrinkage in patients with nonfunctioning pituitary adenomas. Pituitary (2013) 16:189-94. doi: 10.1007/s11102-012-0403-y

91. Freda PU, Beckers AM, Katznelson L, Molitch ME, Montori VM, Post KD, et al. Pituitary incidentaloma: an endocrine society clinical practice guideline. J Clin Endocrinol Metab. (2011) 96:894-904. doi: 10.1210/jc.2010-1048

92. Chanson P, Raverot G, Castinetti F, Cortet-Rudelli C, Galland F, Salenave $\mathrm{S}$, et al. Management of clinically non-functioning pituitary adenoma. Ann Endocrinol. (2015) 76:239-47. doi: 10.1016/j.ando.2015.04.002

Conflict of Interest Statement: The authors declare that the research was conducted in the absence of any commercial or financial relationships that could be construed as a potential conflict of interest.

Copyright (๑) 2018 Cooper and Greenman. This is an open-access article distributed under the terms of the Creative Commons Attribution License (CC BY). The use, distribution or reproduction in other forums is permitted, provided the original author(s) and the copyright owner(s) are credited and that the original publication in this journal is cited, in accordance with accepted academic practice. No use, distribution or reproduction is permitted which does not comply with these terms. 